\title{
Obesity in older adults: epidemiology and implications for disability and disease
}

\author{
Rafael Samper-Ternent ${ }^{1}$ and Soham Al Snih ${ }^{1,2,3}$ \\ ${ }^{1}$ Sealy Center on Ageing, ${ }^{2}$ Division of Rehabilitation Sciences and ${ }^{3}$ Division of Geriatrics, Department of Internal \\ Medicine, University of Texas Medical Branch, Galveston, Texas, USA
}

\begin{abstract}
Summary
Obesity is a worldwide problem with increasing prevalence and incidence in both developed and developing countries. In older adults, excess weight is associated with a higher prevalence of cardiovascular disease, metabolic disease, several important cancers, and numerous other medical conditions. Obesity has also been associated with increased functional limitations, disability, and poorer quality of life. Additionally, obesity has been independently associated with all-cause mortality. The obesity epidemic has important social and economic implications, representing an important source of increased public health care costs. The aim of this review is to report the epidemiology of obesity worldwide, and the implications of obesity on disability and chronic diseases in older adults.
\end{abstract}

Key words: obesity, older adults, disability, chronic disease.

\section{Introduction}

Obesity is a health concern in both developed and developing countries. Numerous studies have documented an increase in the prevalence of obesity worldwide, a trend that has been described as an 'epidemic'. Increases in the prevalence of obesity have been observed in men and women, in all age groups, in all major ethnic groups, and at all educational levels. According to the World Health Organization (WHO), obesity prevalence has doubled since $1980 .{ }^{1}$ Some authors argue that up to one-third of the life expectancy gains over time attributable to public health achievements, such as reductions in smoking, are counteracted by the simultaneous increase in obesity prevalence. ${ }^{2.3}$ Among older adults, obesity has been related to higher rates of disability and poor overall health. ${ }^{4}$

Address for correspondence: Soham Al Snih, Rebecca Sealy Bldg room 5.112, 301 University Blvd, Galveston, TX 77555-0177, USA.

Email: soalsnih@utmb.edu
This is especially relevant given the expected worldwide growth of older adult populations.

We searched Medline, PubMed, EMBASE and World of Science databases and websites for the World Health Organization, and for major longitudinal studies on ageing such as the English Longitudinal Study on Ageing (ELSA) (http://www.esds.ac.uk/longitudinal/access/elsa/), the Survey of Health, Ageing and Retirement in Europe (SHARE) (http://www.shareproject.org/), the Health and Retirement Study (HRS) (http://hrsonline.isr.umich.edu/), and The Health, Well-Being, and Ageing Survey (SABE) (http://www.ssc.wisc.edu/sabe). We did not limit the search by type of study given the complexity of the topics addressed; however, we did limit the search to manuscripts published in core clinical and epidemiological journals between 1991 and 2011, given the focus of the review. Our initial search terms included 'obesity', 'prevalence', 'trends', 'older adults' and 'epidemiology'. We went on to conduct several further searches to find articles related to obesity and disability and obesity and chronic diseases for each of the sub-sections covered in this article.

\section{Epidemiology of obesity around the world}

Comparisons between regions around the world indicate a wide variation in prevalence of obesity. Despite these regional differences, over time the prevalence of obesity has increased worldwide. ${ }^{1}$ Table 1 summarizes the prevalence of obesity according to studies published in the last two decades using information from three regions in the world: North America (USA and Canada), Latin America and Europe.

In the United States, studies using data from the National Health and Nutrition Examination Survey (NHANES) report increasing trends in obesity over time. ${ }^{5-10}$ Ford and colleagues reported 
Table 1. Summary of literature review of studies reporting prevalence of obesity around the world in the past two decades

\begin{tabular}{|c|c|c|c|c|c|c|c|}
\hline Author & Year & $\begin{array}{l}\text { Age } \\
\text { inclusion } \\
\text { (years) }\end{array}$ & Type of study & $\begin{array}{l}\text { BMI cut-off } \\
\text { points }\end{array}$ & Mean BMI or prevalence & Region & Notes \\
\hline MacDonald $^{14}$ & 1997 & $18-74$ & $\begin{array}{l}\text { Cross-sectional surveys } \\
\text { conducted in ten Canadian } \\
\text { provinces between 1986-1992 }\end{array}$ & $\begin{array}{l}\text { Obesity } \\
\quad \text { considered } \\
\text { as } \mathrm{BMI} \geq \\
27\end{array}$ & $\begin{array}{l}\text { Mean BMI for men was } 25.8 \\
\text { (SD } 4.03 \text { ) and } 24.9 \text { (SD } \\
5.14 \text { ) for women. A total } \\
\text { of } 35 \% \text { of men and } 27 \% \\
\text { of women were } \\
\text { considered to be obese }\end{array}$ & $\begin{array}{l}\text { North } \\
\text { America }\end{array}$ & $\begin{array}{l}\text { Additional study conducted } \\
\text { with same data set by the } \\
\text { same group reported no } \\
\text { differences in BMI between } \\
\text { urban and rural areas of } \\
\text { Canada }\end{array}$ \\
\hline Torrance $^{13}$ & 2002 & $20-69$ & $\begin{array}{l}\text { Cross-sectional study using three } \\
\text { different national surveys to } \\
\text { determine trend in obesity of } \\
\text { adults in Canada }\end{array}$ & $\begin{array}{l}\text { WHO cut-off } \\
\text { points }\end{array}$ & $\begin{array}{l}\text { Prevalence of obesity } \\
\text { increased over time for } \\
\text { men from } 8.1 \% \\
(1970-72) \text { to } 12 \% \\
(1978-79) \text { to } 13.4 \% \\
\text { (1986-1992). Similarly } \\
\text { for women the prevalence } \\
\text { increased from } 12.7 \% \\
(1970-72) \text { to } 14.9 \% \\
(1978-79) \text { to } 15.4 \% \\
(1986-1992)\end{array}$ & $\begin{array}{l}\text { North } \\
\text { America }\end{array}$ & $\begin{array}{l}\text { No differences observed by } \\
\text { education; however, smoking } \\
\text { status had a strong } \\
\text { relationship with increasing } \\
\text { obesity trends }\end{array}$ \\
\hline Kaplan $^{12}$ & 2003 & $\geq 65$ & $\begin{array}{l}\text { Cross-sectional study using wave } \\
2 \text { (1996-1997) of the CNPHS } \\
\text { survey }\end{array}$ & $\begin{array}{l}\text { WHO cut-off } \\
\text { points }\end{array}$ & $\begin{array}{l}\text { A total of } 12.8 \% \text { of older } \\
\text { adults fell under the obese } \\
\text { category }\end{array}$ & $\begin{array}{l}\text { North } \\
\text { America }\end{array}$ & $\begin{array}{l}\text { Overall, men were } 37 \% \text { more } \\
\text { likely to be obese than } \\
\text { women. Obesity was also } \\
\text { more common among } \\
\text { younger senior adults; less } \\
\text { educated; unmarried; } \\
\text { non-smokers; infrequent and } \\
\text { heavier alcohol users; } \\
\text { physically inactive; more } \\
\text { co-morbidities; functional } \\
\text { limitations; poorer self-rated } \\
\text { health; and reporting } \\
\text { psychological distress. Place } \\
\text { of birth also predicted obesity }\end{array}$ \\
\hline
\end{tabular}




\begin{tabular}{|c|c|c|c|c|c|c|c|}
\hline Crimmins $^{7}$ & 2005 & $\geq 65$ & Longitudinal & $\begin{array}{l}\text { WHO cut-off } \\
\text { points }\end{array}$ & $\begin{array}{l}\text { Prevalence increased from } \\
21.4 \%(1988-94) \text { to } \\
30.8 \%(1999-2000)\end{array}$ & $\begin{array}{l}\text { North } \\
\text { America }\end{array}$ & NHANES III and IV data \\
\hline Ford $^{9}$ & 2009 & $25-74$ & Cross-sectional & $\begin{array}{l}\text { WHO cut-off } \\
\text { points }\end{array}$ & $\begin{array}{l}\text { Age-adjusted prevalence of } \\
\text { obesity: } 11.1 \% \\
\text { (1971-75); } 10.9 \% \\
(1976-80) ; 15.5 \% \\
(1988-94) ; 19.3 \% \\
(1999-2004)\end{array}$ & $\begin{array}{l}\text { North } \\
\text { America }\end{array}$ & NHANES \\
\hline Bleich $^{5}$ & 2009 & $\geq 20$ & Cross-sectional & $\begin{array}{l}\text { WHO cut-off } \\
\text { points }\end{array}$ & $\begin{array}{l}\text { Prevalence of obesity } \\
\text { reported at } 22 \% \\
\text { (1988-94) and } 31 \% \\
(1999-2004)\end{array}$ & $\begin{array}{l}\text { North } \\
\text { America }\end{array}$ & $\begin{array}{l}\text { NHANES. Examines } \\
\text { relationship between } \\
\text { increased consumption of } \\
\text { sugar-sweetened beverages } \\
\text { with increasing prevalence of } \\
\text { obesity }\end{array}$ \\
\hline $\operatorname{Lix}^{16}$ & 2009 & $\geq 20$ & $\begin{array}{l}\text { Cross-sectional study using } 2 \\
\text { waves of the CCHS (2000-01 } \\
\text { and 2005-06) }\end{array}$ & $\begin{array}{l}\text { WHO cut-off } \\
\text { points }\end{array}$ & $\begin{array}{l}\text { At baseline } 20 \% \text { of the } \\
\text { population was obese. } \\
\text { Between baseline and } \\
\text { follow-up there was an } \\
\text { increase in prevalence of } \\
\text { obesity but only for } \\
\text { Aboriginal participants. } \\
\text { Prevalence of obesity at } \\
\text { baseline for Aboriginals } \\
\text { was } 20.2 \%(95 \% \mathrm{CI} \\
18.1-22.4) \text { and } 18.5 \% \\
(95 \% \mathrm{CI} 15.9-21.0) \text { for } \\
\text { non-Aboriginals. At } \\
\text { follow-up the prevalence } \\
\text { was } 25.4 \% \text { ( } 95 \% \mathrm{CI} \\
20.5-30.2) \text { and } 21.1 \% \\
(18.3-23.9) \text { for } \\
\text { Aboriginals and } \\
\text { non-Aboriginals, } \\
\text { respectively }\end{array}$ & $\begin{array}{l}\text { North } \\
\text { America }\end{array}$ & $\begin{array}{l}\text { Cover three regions of northern } \\
\text { Canada. Variations in } \\
\text { prevalence of obesity } \\
\text { observed by ethnic group and } \\
\text { region }\end{array}$ \\
\hline
\end{tabular}


Table 1. (continued)

\begin{tabular}{|c|c|c|c|c|c|c|c|}
\hline Author & Year & $\begin{array}{l}\text { Age } \\
\text { inclusion } \\
\text { (years) }\end{array}$ & Type of study & $\begin{array}{l}\text { BMI cut-off } \\
\text { points }\end{array}$ & Mean BMI or prevalence & Region & Notes \\
\hline Cohen $^{6}$ & 2010 & $20-74$ & $\begin{array}{l}\text { Analysis of trends using data } \\
\text { from NHANES I, II and III }\end{array}$ & $\begin{array}{l}\text { WHO cut-off } \\
\text { points }\end{array}$ & $\begin{array}{l}\text { Mean BMI for each } \\
\text { cross-section: } 25.5( \pm 5.0) \\
(1976-80) ; 27.3( \pm 5.9) \\
(1988-94) ; 28.7( \pm 6.6) \\
(1999-2006) . \text { Prevalence } \\
\text { of obesity for each } \\
\text { cross-section: } 15 \% \\
(1976-80), 26 \% \\
(1988-94) \text { and } 34 \% \\
(1999-2006)\end{array}$ & $\begin{array}{l}\text { North } \\
\text { America }\end{array}$ & $\begin{array}{l}\text { NHANES 1976-2006 data. } \\
\text { Examined trends in serum } \\
\text { lipids as main outcome. Only } \\
\text { individuals with } 1 \text { or more } \\
\text { total cholesterol or lipid } \\
\text { results were included }\end{array}$ \\
\hline Flegal $^{8}$ & 2010 & $\geq 20$ & $\begin{array}{l}\text { Analysis of trends using } \\
\text { cross-sectional data from } \\
\text { NHANES between 1999-2000 } \\
\text { and 2007-08 }\end{array}$ & $\begin{array}{l}\text { WHO cut-off } \\
\text { points }\end{array}$ & $\begin{array}{l}\text { In } 2007-08 \text { the age-adjusted } \\
\text { prevalence of obesity was } \\
33.8 \%(95 \% \text { CI } \\
31.6-63.0 \%) \text {. For men it } \\
\text { was } 32.2 \%(95 \% \text { CI } \\
29.5-35.0) \text { and for } \\
\text { women } 35.5 \% \text { (95\% CI } \\
33.2-37.7) \text {. }\end{array}$ & $\begin{array}{l}\text { North } \\
\text { America }\end{array}$ & $\begin{array}{l}\text { Differences observed by gender } \\
\text { and race/ethnicity. Between } \\
1999-2000 \text { and 2007-08 a } \\
4.7 \% \text { increase in obesity for } \\
\text { men and } 2.1 \% \text { increase for } \\
\text { women were observed. } \\
\text { Prevalence change for } \\
\text { women was not significant. } \\
\text { Prevalence of overweight and } \\
\text { obesity was } 68 \%\end{array}$ \\
\hline Stenholm ${ }^{11}$ & 2010 & $\geq 60$ & Longitudinal study in Baltimore & $\begin{array}{l}\text { WHO cut-off } \\
\text { points }\end{array}$ & $\begin{array}{l}\text { Mean BMI for men of three } \\
\text { different cohorts from the } \\
\text { BLSA study: } 24.2( \pm 3) \\
(1877-99) ; 25.2( \pm 3.2) \\
(1900-19) ; 27.5( \pm 4.3) \\
(1920-43)\end{array}$ & $\begin{array}{l}\text { North } \\
\text { America }\end{array}$ & $\begin{array}{l}\text { Secular increase in body weight } \\
\text { in three cohorts of older } \\
\text { white men in the US } \\
\text { independent of body height. } \\
\text { BLSA study }\end{array}$ \\
\hline Ford $^{10}$ & 2011 & $\geq 20$ & $\begin{array}{l}\text { Analysis of trends using } \\
\text { cross-sectional data between } \\
\text { 1999-2000 and 2007-08 }\end{array}$ & $\begin{array}{l}\text { WHO cut-off } \\
\text { points }\end{array}$ & $\begin{array}{l}\text { Age-adjusted mean BMI for } \\
\text { men } 26.9 \text { in 1999-2000 } \\
\text { and } 32 \text { in } 2007-08 \text {; in } \\
\text { women } 33.2 \text { in } \\
1999-2000 \text { and } 35.2 \text { in } \\
\text { 2007-08 }\end{array}$ & $\begin{array}{l}\text { North } \\
\text { America }\end{array}$ & $\begin{array}{l}\text { Analyses trends in obesity and } \\
\text { abdominal obesity using } \\
\text { NHANES data }\end{array}$ \\
\hline
\end{tabular}




\begin{tabular}{|c|c|c|c|c|c|c|c|}
\hline Bruce $^{15}$ & 2010 & $\geq 18$ & $\begin{array}{l}\text { Cross-sectional } \\
\text { study using data } \\
\text { from an } \\
\text { Aboriginal group } \\
\text { in Canada }\end{array}$ & $\begin{array}{l}\text { WHO cut-off } \\
\text { points }\end{array}$ & $\begin{array}{l}\text { A total of } 56 \% \text { of the sample were obese. A } \\
\text { total of } 50 \% \text { of men and } 65 \% \text { of women } \\
\text { were obese }\end{array}$ & $\begin{array}{l}\text { North } \\
\text { America }\end{array}$ & $\begin{array}{l}\text { Analyses one group of } \\
\text { Aboriginals. Aboriginals in } \\
\text { Canada are considered to } \\
\text { have poorer overall health } \\
\text { compared with other ethnic } \\
\text { groups in Canada }\end{array}$ \\
\hline $\begin{array}{l}\text { Ruiz- } \\
\text { Arregui }^{19}\end{array}$ & 2005 & $\geq 60$ & $\begin{array}{l}\text { Cross-sectional } \\
\text { study using the } \\
\text { first wave (2001) } \\
\text { of the MHAS }\end{array}$ & $\begin{array}{l}\text { WHO cut-off } \\
\text { points }\end{array}$ & $\begin{array}{l}\text { Obesity was present in } 20.9 \% \text { of the total } \\
\text { population. A total of } 24.8 \% \text { of women } \\
\text { and } 17.3 \% \text { of men were obese }\end{array}$ & $\begin{array}{l}\text { Latin } \\
\text { America }\end{array}$ & $\begin{array}{l}\text { Hypertension and limitations in } \\
\text { walking were associated with } \\
\text { higher prevalence of obesity }\end{array}$ \\
\hline Monteiro $^{18}$ & 2007 & $\geq 20$ & $\begin{array}{l}\text { Uses cross-sectional } \\
\text { data from } 3 \\
\text { national surveys } \\
\text { in Brazil (1975, } \\
1989,2003) \text { to } \\
\text { estimate trends in } \\
\text { obesity }\end{array}$ & $\begin{array}{l}\text { WHO cut-off } \\
\text { points }\end{array}$ & $\begin{array}{l}\text { Mean BMI in men: 22.4 SE 0.08 (1975), } \\
23.5 \text { SE 0.07 (1989), 24.6 SE 0.04 } \\
\text { (2003). Mean BMI in women: } 23.0 \text { SE } \\
0.08(1975), 24.5 \text { SE } 0.07 \text { (1989), } 24.7 \\
\text { SE 0.04 (2003). Prevalence of obesity } \\
\text { was } 2.7 \% \text { in } 1975,5.1 \% \text { in } 1989 \text { and } \\
8.8 \% \text { in } 2003 \text { for men, and } 7.4,12.4 \\
\text { and } 13 \% \text { for women in the same years }\end{array}$ & $\begin{array}{l}\text { Latin } \\
\text { America }\end{array}$ & $\begin{array}{l}\text { Obesity trends in men increased } \\
\text { but in women remained the } \\
\text { same between } 1989 \text { and } \\
2003 \text { compared with } \\
1975-1989 . \text { Increases in } \\
\text { obesity were more prevalent } \\
\text { in lower SES quintiles for } \\
\text { both men and women }\end{array}$ \\
\hline Al Snih ${ }^{44}$ & 2010 & $\geq 65$ & $\begin{array}{l}\text { Cross-sectional } \\
\text { study using data } \\
\text { from the SABE } \\
\text { study that } \\
\text { included } 6 \text { cities } \\
\text { in Latin America } \\
\text { and the } \\
\text { Caribbean }\end{array}$ & $\begin{array}{l}\text { WHO cut-off } \\
\text { points, } \\
\text { separates } \\
\text { category I } \\
\text { (BMI } \\
\text { between } 30 \\
\text { and 34.9) } \\
\text { from } \\
\text { category II } \\
\text { and } \\
\text { extreme } \\
\text { obesity } \\
\text { (BMI } \geq 35 \text { ) }\end{array}$ & $\begin{array}{l}\text { Mean BMI for the different cities: } \\
\text { Bridgetown, Barbados } 26.9 \text { (95\% CI } \\
\text { 26.4-27.3); Sao Paolo, Brazil } 26.4 \text { (95\% } \\
\text { CI 26.1-26.7); Santiago, Chile } 27.7 \\
\text { (95\% CI 27.2-28.2); Havana, Cuba } \\
24.2 \text { (95\% CI 23.9-24.5); Mexico City, } \\
\text { Mexico 27.5 (95\% CI 27.1-27.8); } \\
\text { Montevideo, Uruguay 28.3 (95\% CI } \\
\text { 27.9-28.8). The prevalence of category I } \\
\text { obesity was: Bridgetown, Barbados } \\
\text { 15.2\% (95\% CI 13.1-17.4); Sao Paolo, } \\
\text { Brazil 17.6\% (95\% CI 15.5-19.8); } \\
\text { Santiago, Chile 22.9\% (95\% CI } \\
\text { 20.1-25.8); Havana, Cuba 10.4\% (95\% } \\
\text { CI 8.4-12.4); Mexico City, Mexico } \\
\text { 21.3\% (95\% CI 18.2-24.4); } \\
\text { Montevideo, Uruguay 21.9\% (95\% CI } \\
\text { 18.5-25.3). The range for category II } \\
\text { and extreme obesity was between } 2.9 \\
\text { and } 15.7 \%\end{array}$ & $\begin{array}{l}\text { Latin } \\
\text { America }\end{array}$ & $\begin{array}{l}\text { Obesity is an independent } \\
\text { factor contributing to ADL } \\
\text { disability. Category I and } \\
\text { category II obesity are } \\
\text { presented separately. We } \\
\text { added both percentages to } \\
\text { report prevalence of obesity } \\
\text { overall }\end{array}$ \\
\hline
\end{tabular}




\begin{tabular}{|c|c|c|c|c|c|c|c|}
\hline Author & Year & $\begin{array}{l}\text { Age } \\
\text { inclusion } \\
\text { (years) }\end{array}$ & Type of study & $\begin{array}{l}\text { BMI cut-off } \\
\text { points }\end{array}$ & Mean BMI or prevalence & Region & Notes \\
\hline Morabia $^{26}$ & 2005 & $35-74$ & $\begin{array}{l}\text { Cross-sectional yearly interviews } \\
\text { of people in Switzerland } \\
\text { between 1993-2003 }\end{array}$ & $\begin{array}{l}\text { WHO cut-off } \\
\text { points }\end{array}$ & $\begin{array}{l}\text { Prevalence of obesity } \\
\text { increased from } 9 \% \text { in } \\
1993 \text { to } 15 \% \text { in } 2003 \text { in } \\
\text { men; in women it } \\
\text { increased from } 7 \text { to } 11 \%\end{array}$ & Europe & Age-adjusted trends \\
\hline Andreyeva ${ }^{21}$ & 2007 & $\geq 50$ & $\begin{array}{l}\text { Cross-sectional data study using } \\
\text { data from the first wave of } \\
\text { SHARE (2004), a panel study } \\
\text { including eleven countries in } \\
\text { Europe }\end{array}$ & $\begin{array}{l}\text { WHO cut-off } \\
\text { points }\end{array}$ & $\begin{array}{l}\text { Obesity was present in } \\
16.2 \% \text { of men and } 17.8 \% \\
\text { of women. The prevalence } \\
\text { for each country was as } \\
\text { follows: } 17.9 \% \text { in Austria, } \\
14 \% \text { in Denmark, } 15.1 \% \\
\text { in France, } 16.9 \% \text { in } \\
\text { Germany, } 16.8 \% \text { in } \\
\text { Greece, } 15.2 \% \text { in Italy, } \\
13 \% \text { in the Netherlands, } \\
20.2 \% \text { in Spain, } 12.8 \% \text { in } \\
\text { Sweden, } 13 \% \text { in } \\
\text { Switzerland; for women } \\
\text { the prevalence was: } \\
19.7 \% \text { in Austria, } 13.3 \% \\
\text { in Denmark, } 15.1 \% \text { in } \\
\text { France, } 17.4 \% \text { in } \\
\text { Germany, } 21.9 \% \text { in } \\
\text { Greece, } 17.1 \% \text { in Italy, } \\
16.5 \% \text { in the Netherlands, } \\
25.6 \% \text { in Spain, } 14.4 \% \text { in } \\
\text { Sweden, } 12.3 \% \text { in } \\
\text { Switzerland }\end{array}$ & Europe & \\
\hline Charles $^{22}$ & 2008 & $\geq 18$ & $\begin{array}{l}\text { Uses cross-sectional data from } 4 \\
\text { national surveys in France } \\
(1997,2000,2003,2006) \text { to } \\
\text { examine trends in obesity }\end{array}$ & $\begin{array}{l}\text { WHO cut-off } \\
\text { points }\end{array}$ & $\begin{array}{l}\text { Prevalence of obesity } \\
\text { increased from } 8.6 \% \\
(95 \% \text { CI } 8.2-8.8) \text { in } 1997 \\
\text { to } 13.1 \%(95 \% \text { CI } \\
12.7-13.5) \text { in } 2006\end{array}$ & Europe & $\begin{array}{l}\text { Parallel increase in obesity } \\
\text { trends for men and women } \\
\text { between 1997-2003 but } \\
\text { slightly lower in men } \\
\text { between 2003-2006 }\end{array}$ \\
\hline
\end{tabular}




\begin{tabular}{|c|c|c|c|c|c|c|c|}
\hline Lang $^{25}$ & 2008 & $\geq 65$ & $\begin{array}{l}\text { Longitudinal study using } \\
\text { data from ELSA to } \\
\text { predict mortality and } \\
\text { disability by BMI status }\end{array}$ & $\begin{array}{l}\text { WHO cut-off } \\
\text { points }\end{array}$ & $\begin{array}{l}\text { Prevalence of obesity at baseline } \\
\text { was } 19.4 \% \text { for men and } 28.9 \% \\
\text { for women }\end{array}$ & Europe & $\begin{array}{l}\text { Obesity at baseline was related } \\
\text { to higher risk of mortality } \\
\text { and disability }\end{array}$ \\
\hline Kotseva $^{20}$ & 2009 & $<=70$ & $\begin{array}{l}\text { Cross-sectional study using } \\
\text { EUROASPIRE I, II and } \\
\text { III data }\end{array}$ & $\begin{array}{l}\text { WHO cut-off } \\
\text { points }\end{array}$ & $\begin{array}{l}\text { Age and diagnosis adjusted: } 25 \% \\
\quad(1995-96) ; 32.6 \% \\
(1999-2000) ; 38 \%(2006-07)\end{array}$ & Europe & $\begin{array}{l}\text { EUROASPIRE I-III are } \\
\text { cross-sectional studies } \\
\text { conducted in acute hospitals } \\
\text { in } 8 \text { European countries } \\
\text { (Czech Republic, Finland, } \\
\text { France, Germany, Hungary, } \\
\text { Italy, the Netherlands, and } \\
\text { Slovenia) to identify } \\
\text { prevalence of cardiovascular } \\
\text { risk factors. Interviews were } \\
\text { conducted in 1995-96, } \\
1999-2000 \text { and 2006-2007. } \\
\text { Large variation by country } \\
\text { was observed. EUROASPIRE } \\
\text { studies are hospital-based } \\
\text { convenient samples }\end{array}$ \\
\hline Dugravot $^{23}$ & 2010 & $45-65$ & Longitudinal & $\begin{array}{l}\text { WHO cut-off } \\
\text { points }\end{array}$ & $\begin{array}{l}\text { Obesity rates for men were } 3.4 \\
\text { and } 7.7 \% \text { for managers and } \\
\text { unskilled workers, respectively, } \\
\text { at age } 45 \text { and } 9.5 \text { and } 18.1 \% \\
\text { for managers and unskilled } \\
\text { workers, respectively, at age } 65 \text {. } \\
\text { Statistically significant increases } \\
\text { in BMI trajectories in } 20 \text {-year } \\
\text { period for men and women by } \\
\text { education and occupation } \\
\text { category }\end{array}$ & Europe & $\begin{array}{l}\text { Examined socioeconomic } \\
\text { differences in trajectories of } \\
\text { BMI and obesity between age } \\
45 \text { and } 65 \text { in France }\end{array}$ \\
\hline Hubbard ${ }^{24}$ & 2010 & $\geq 65$ & $\begin{array}{l}\text { Cross-sectional study using } \\
\text { wave } 2 \text { (2004) of the } \\
\text { ELSA study }\end{array}$ & $\begin{array}{l}\text { WHO cut-off } \\
\text { points }\end{array}$ & $\begin{array}{l}\text { Mean BMI for the sample was } \\
27.5 \text { ( } 95 \% \text { CI } 27.4-27.7) \text {. } \\
\text { Prevalence of obesity was } \\
29.1 \% \text { for women and } 23.4 \% \\
\text { in men }\end{array}$ & Europe & $\begin{array}{l}\text { Analysed the relationship } \\
\text { between BMI and frailty and } \\
\text { examined differences by } \\
\text { frailty definition used }\end{array}$ \\
\hline
\end{tabular}


Table 1. (continued)

\begin{tabular}{|c|c|c|c|c|c|c|c|}
\hline Author & Year & $\begin{array}{l}\text { Age } \\
\text { inclusion } \\
\text { (years) }\end{array}$ & Type of study & $\begin{array}{l}\text { BMI cut-off } \\
\text { points }\end{array}$ & Mean BMI or prevalence & Region & Notes \\
\hline $\begin{array}{l}\text { Gomez- } \\
\text { Cabello }\end{array}$ & 2011 & $\geq 65$ & Longitudinal study in Spain & $\begin{array}{l}\text { WHO cut-off } \\
\text { points }\end{array}$ & $\begin{array}{l}\text { Prevalence of obesity was } 40.9 \% \\
\text { for women and } 26.6 \% \text { for men, } \\
\text { the overall rate was } 37.6 \%\end{array}$ & Europe & $\begin{array}{l}\text { Differences reported using } \\
\text { waist circumference, BMI } \\
\text { and body fat }\end{array}$ \\
\hline Banks $^{99}$ & 2006 & $55-64$ & $\begin{array}{l}\text { Cross-sectional data from } \\
\text { two studies: } 2002 \text { HRS } \\
\text { in the US and } 2002 \\
\text { ELSA in the UK }\end{array}$ & $\begin{array}{l}\text { WHO cut-off } \\
\text { points }\end{array}$ & $\begin{array}{l}\text { Prevalence was } 23.0 \% \text { for the UK } \\
\text { and } 31.1 \% \text { for the US }\end{array}$ & $\begin{array}{l}\text { Comparison } \\
\text { between } \\
\text { regions - } \\
\text { USA + } \\
\text { Europe }\end{array}$ & $\begin{array}{l}\text { Significant difference at the } \\
0.01 \text { level, controlling for } \\
\text { income and education }\end{array}$ \\
\hline Michaud $^{28}$ & 2007 & $\geq 50$ & $\begin{array}{l}\text { Cross-sectional data } \\
\text { comparing data from the } \\
\text { HRS (2004) and the first } \\
\text { wave of SHARE (2004) }\end{array}$ & $\begin{array}{l}\text { WHO cut-off } \\
\text { points }\end{array}$ & $\begin{array}{l}\text { Obesity was present in } 30.7 \% \text { of } \\
\text { men in the USA and } 17.6 \% \text { in } \\
\text { Europe and } 37.9 \% \text { of women in } \\
\text { USA and } 24.2 \% \text { of women in } \\
\text { Europe. The prevalence of } \\
\text { obesity by European country for } \\
\text { men was: } 19.8 \% \text { in Austria, } \\
18.6 \% \text { in Germany, } 15.8 \% \text { in } \\
\text { Sweden, } 15.3 \% \text { in the } \\
\text { Netherlands, } 20.8 \% \text { in Spain, } \\
15.6 \% \text { in Italy, } 16.2 \% \text { in } \\
\text { France, } 17.5 \% \text { in Denmark and } \\
19.2 \% \text { in Greece. The } \\
\text { prevalence of obesity by } \\
\text { European country for women } \\
\text { was: } 26.9 \% \text { in Austria, } 22.9 \% \\
\text { in Germany, } 21.5 \% \text { in Sweden, } \\
23.2 \% \text { in the Netherlands, } \\
33.6 \% \text { in Spain, } 23.4 \% \text { in Italy, } \\
20.3 \% \text { in France, } 18.2 \% \text { in } \\
\text { Sweden and } 31.2 \% \text { in Greece }\end{array}$ & $\begin{array}{l}\text { Comparison } \\
\text { between } \\
\text { regions - } \\
\text { USA + } \\
\text { Europe }\end{array}$ & $\begin{array}{l}\text { BMI is corrected for } \\
\text { self-report bias using } \\
\text { formula derived from } \\
\text { NHANES study (Cawley } \\
\text { \& Burkhauser, 2006) }\end{array}$ \\
\hline
\end{tabular}




\begin{tabular}{|c|c|c|c|}
\hline Avendano ${ }^{100}$ & 2009 & $50-74$ & $\begin{array}{l}\text { Cross-sectional data in } 2004 \\
\text { comparing three studies: } \\
\text { HRS in USA, ELSA in } \\
\text { England and SHARE in } \\
\text { Europe }\end{array}$ \\
\hline Young $^{29}$ & 2007 & $\geq 18$ & $\begin{array}{l}\text { Cross-sectional study using } \\
4 \text { studies of Inuit people ( } 1 \\
\text { in Alaska, } 2 \text { in Canada } \\
\text { and } 1 \text { in Greenland) } \\
\text { conducted between } 1990 \\
\text { and } 2001\end{array}$ \\
\hline Stewart ${ }^{3}$ & 2009 & $\geq 18$ & $\begin{array}{l}\text { Uses cross-sectional data to } \\
\text { estimate trends in obesity } \\
\text { and estimate impact on } \\
\text { mortality in } 2020\end{array}$ \\
\hline
\end{tabular}
WHO cut-off points
Prevalence of obesity: $28.8 \%$ in USA, $26.1 \%$ in obesity
WHO cut-off 25.2 (1973-79); 26.5
points $\quad(1990) ; 27.9(2000) ; 28.3$
(2005)

Comparison

between

regions -

USA +

Europe
WHO cut-off A total of $15.8 \%$ of Inuit points men had obesity while $25.5 \%$ of women had
Multi-country No significant differences study of between countries were
Inuit people observed

North America Forecasts of life expectancy in the United States for a representative 18 -year-old assuming trends in smoking and BMI remain constant. Project $45 \%$ of US population will be obese by 2020. NHANES

CNPHS, Canadian National Population Health Survey; NHANES, National Health and Nutrition Examination Survey (USA); ELSA, English Longitudinal Study of Ageing; SHARE, Survey of Health, Ageing and Retirement in Europe; SABE, Health, Well-being and Ageing Survey (Latin America and the Caribbean); MHAS, Mexican Health and Ageing Study. BLSA, Baltimore Longitudinal Study of Aging; EUROASPIRE, Europe Action on Secondary and Primary Interventions to Reduce Events; WHO, World Health Organization; BMI, body mass index; WHO cut-off points, BMI $\geq 30 \mathrm{~kg} / \mathrm{m}^{2}$. 
an increase in the prevalence of obesity from $11.1 \%$ in the 1970 s to $19.3 \%$ in the early 2000 s. ${ }^{9}$ The most recent data from NHANES report obesity prevalence to be approximately $32 \%$ for men and $36 \%$ for women. ${ }^{8,10}$ The difference between men and women is not statistically significant based on the overlapping confidence intervals. Nevertheless, the trend over time has continued to increase for men, while for women it seems to be stabilizing. ${ }^{8,11}$ Race/ethnic differences are also reported in the increasing obesity trends, with AfricanAmericans having the highest rates, followed by Hispanics. $^{8}$

Obesity in Canada is lower. The overall prevalence of obesity in the mid-1990s was reported at $12.8 \%,{ }^{12}$ half that reported in the USA using data from the NHANES study in a similar time period (Table 1). A steady rise in the obesity trends is observed in Canada as well, with obesity rates of $8.1 \%$ for men in the 1970 s increasing to $13.4 \%$ in the $1990 \mathrm{~s}$, and rates of $12.7 \%$ rising to $15.4 \%$ in women. ${ }^{13}$ MacDonald and colleagues, using the cut-off point of $27 \mathrm{~kg} / \mathrm{m}^{2}$ for obesity, found obesity rate of $35 \%$ for men and $27 \%$ for women in ten provinces from Canada. ${ }^{14}$ The lower cut-off point explains the large difference in the prevalence between this and the other Canadian studies (Table 1). Nevertheless, we cannot determine why the prevalence rate is higher in men than in women, in contrast to studies in North America. Ethnic differences are also observed in Canada, with Aboriginals reporting higher rates of obesity. ${ }^{15,16}$

The few studies available on prevalence of obesity in Latin America and the Caribbean in older adults also report an increase over time. A large variation between countries is also observed. ${ }^{17-19}$ Using data from The Health, WellBeing and Ageing Survey (SABE), the prevalence of category I obesity (BMI of 30 to $<35 \mathrm{~kg} / \mathrm{m}^{2}$ ) for men and women combined, ranged between $10.4 \%$ in Havana to $22.9 \%$ in Santiago; the prevalence of category II and extreme obesity (BMI $\geq$ $35 \mathrm{~kg} / \mathrm{m}^{2}$ ) ranged from $2.9 \%$ in Havana to $15.7 \%$ in Montevideo. ${ }^{17}$ Thus obesity of any category ranged between 13.3 and $38.6 \%$ in the SABE study (Table 1). The two remaining studies summarized in Table 1 on Latin America were conducted only in Brazil and Mexico. In Brazil the prevalence of obesity seemed to reach a plateau in the early 2000 s for women, while for men the trend continued to increase. ${ }^{18}$ The prevalence reported in the single country studies falls in the range reported in the SABE study (Table 1).

In Europe, both cross-sectional and longitudinal studies report a large variation in the prevalence of obesity between countries. Using data from the Europe Action on Secondary and Primary Intervention through Intervention to Reduce Events (EUROASPIRE) surveys, the average prevalence of obesity increased from $25 \%$ in EUROASPIRE I to $38 \%$ in EUROASPIRE III. ${ }^{20}$ Studies using data from the Survey of Health, Ageing and Retirement in Europe (SHARE) and the English Longitudinal Study of Ageing (ELSA) reported average prevalence of obesity for men of $16.2 \%$, and $17.8 \%$ for women. ${ }^{21}$ Nevertheless the variation observed ranges between $12.8 \%$ for men in Sweden to $20.2 \%$ for men in Spain, and between $12.3 \%$ for women in Switzerland to $21.9 \%$ for women in Greece (Table 1). Studies using data from only one country also reported a difference in the prevalence of obesity between men and women and an increasing trend in the prevalence of obesity over time. ${ }^{22-27}$ In most countries the prevalence of obesity is higher for women (Table 1).

Cross-sectional studies comparing the USA with Europe showed that obesity rates in the USA were higher for both men and women (Table 1). In 2004, the prevalence of obesity for the USA was reported at $30.7 \%$ for men compared with $17.6 \%$ in Europe, and $37.9 \%$ in women compared with $24.2 \%$, respectively. ${ }^{28}$ A large variability is noted again between obesity rates in the different European countries. However, no country reaches the exceedingly high obesity rates of the USA. One last study examined obesity rates among Inuit people in Canada, Alaska and Greenland and reported no significant differences between countries, with an overall prevalence of obesity of $15.8 \%$ for Inuit men and $25.5 \%$ for Inuit women. ${ }^{29}$

Finally, Stewart and colleagues used data from the NHANES study to predict obesity rates in 2020 and estimate its impact on mortality. ${ }^{3}$ Their projections showed that life expectancy is decreased by almost 1 year in the USA for a representative 18 -year-old person, assuming trends in smoking continue to decrease and trends in body mass index (BMI) continue to increase at the same rate observed between 1973 and 2005 . Additionally, the projection shows that the overall prevalence of obesity for adults in the USA will be $45 \%$ by the year $2020 .^{3}$ 
We did not include Asia, Africa or Oceania as regions in Table 1 because of the limited number of studies available on the epidemiology of obesity in older adults in these continents. Additionally, a large variability in the prevalence of obesity has been reported in the literature on Asian older adults. However, to include all major regions in the world we analysed two documents that analyse obesity in Asia and Australia. Based on a report by the WHO, the major difficulty with accurately examining obesity among Asians is the large variation in cultural and economic conditions of Asian populations and the fact that current WHO cut-off points for obesity seem to provide an erroneous estimate based on higher prevalence of adverse events at lower BMI values. This report by the WHO proposes that the cut-off point for obesity among Asian adults should be $25 \mathrm{~kg} / \mathrm{m}^{2}{ }^{30}$

The WHO report on Asia summarizes some studies that have looked at epidemiology of obesity. Most data on obesity in Asia come from single country studies or from countries where a large portion of the population is of Asian origin, like the island of Mauritius. Obesity trends are rapidly rising in all Asian nations. Obesity rates range between less than $1 \%$ in rural populations in countries like China, to around $9 \%$ in urban areas of Malaysia. A large variation by gender and ethnicity is observed in several countries including Malaysia and China. In summary, the data from Asian countries reports much lower obesity rates compared with other regions. The WHO, however, strongly advocates for a new definition of obesity with different cut-off points based on the trends in obesity rates and the increase in the prevalence of obesity-associated complications such as cardiovascular diseases.

In Australia, analysis of trends from crosssectional surveys conducted since the 1980s were summarized by the Australian Institute of Health and Welfare in a bulletin published in 2004. ${ }^{31}$ Similar to what has been reported in other continents, the rates of obesity among older adults has increased over time. Between the 1980s and the early 2000s an increase in prevalence of obesity was observed from 11 to $23 \%$ in adults over $65 .{ }^{31}$ The most recent reports show that between 25 and $30 \%$ of adults approaching retirement in Australia are obese.

In summary, obesity has increased noticeably in all continents among older adults. Large variations between countries, race/ethnic groups and genders are observed. Despite these variations, public health implications need to be carefully analysed and addressed to prevent obesity, disability and decreased quality of life for older adults around the world in the near future.

\section{Obesity and disability}

Disability is a broad term that can be defined in many different ways. Lack of a single definition and availability of several validated tools to measure different types of disability make cross-study comparisons on disability difficult. Nevertheless, the ample literature showing that disability increases the risk of mortality and institutionalization and affects quality of life in older age make disability a concept that must be carefully analysed and better understood. ${ }^{32-35}$ Conditions that increase the risk of disability are therefore highly important.

Table 2 summarizes relevant studies that analyse the relationship between obesity and disability. Obesity is not measured consistently although all studies use either BMI, waist circumference or body composition to define obesity. Similarly, the definition of disability varies between the different studies. The first studies listed are longitudinal studies. They are consistent in showing that, over time, the presence of obesity increases the risk of becoming disabled. ${ }^{25,36-43}$ Nevertheless, of the nine longitudinal studies listed, seven studies use activities of daily living (ADL) to define disability. ${ }^{25,36,38,39,41-43}$ Five of the seven studies use the same six activities (walking across a room, bathing, eating, dressing, toileting and transferring in and out of bed) and define disability as difficulty performing one or more activities. ${ }^{25,36,38,39,43}$ From these studies we can conclude that obesity is an independent risk factor for developing ADL disability over time. The remaining studies use upper and lower body function and work-related disability. Each study concludes that obesity increases the risk of the defined disability. ${ }^{37,40}$ The studies by Reynolds et al. and Walter et al. also conclude that obesity hampers the probability of recovery from disability in older adults. ${ }^{38,41}$ In some of the longitudinal studies, the effect of obesity on disability was larger for women compared with men (Table 2).

Following the longitudinal studies, crosssectional studies analysing the relationship between obesity and disability are listed (Table 2). 
Table 2. Summary of literature review of studies analysing the relationship between obesity and disability

\begin{tabular}{|c|c|c|c|c|c|c|c|}
\hline Author & Year & $\begin{array}{l}\text { Age of } \\
\text { participants }\end{array}$ & Type of study & $\begin{array}{l}\text { Obesity } \\
\text { measure used }\end{array}$ & Disability measure used & $\begin{array}{l}\text { Relationship between } \\
\text { obesity and disability }\end{array}$ & Notes \\
\hline Ferraro $^{37}$ & 2002 & $25-74$ & $\begin{array}{l}\text { Longitudinal } \\
\text { study }\end{array}$ & $\begin{array}{l}\text { BMI with } \\
\text { WHO } \\
\text { cut-off } \\
\text { points }\end{array}$ & $\begin{array}{l}\text { A total of } 19 \text { items from the } \\
\text { Stanford Health } \\
\text { Assessment Questionnaire } \\
\text { Disability Index. Nine } \\
\text { items were grouped to } \\
\text { measure lower-body } \\
\text { disability and ten items } \\
\text { were grouped to measure } \\
\text { upper-body disability }\end{array}$ & $\begin{array}{l}\text { At baseline, obesity was } \\
\text { related to upper-body } \\
\text { disability but not } \\
\text { lower-body disability. } \\
\text { Over time, both } \\
\text { underweight and obesity } \\
\text { were related to upper- and } \\
\text { lower-body disability }\end{array}$ & $\begin{array}{l}\text { Relationship between } \\
\text { overweight and disability } \\
\text { was not consistent for the } \\
\text { different groups analysed }\end{array}$ \\
\hline Visscher ${ }^{40}$ & 2004 & $\begin{array}{l}\text { Adults } 20-92 \\
\text { dichotomized } \\
\text { using } 65 \text { as } \\
\text { cut-off point }\end{array}$ & $\begin{array}{l}\text { Longitudinal } \\
\text { study }\end{array}$ & $\begin{array}{l}\text { BMI with } \\
\text { WHO } \\
\text { cut-off } \\
\text { points }\end{array}$ & $\begin{array}{l}\text { Receiving any work } \\
\text { disability pension from the } \\
\text { National Social Insurance } \\
\text { Institutions in Finland }\end{array}$ & $\begin{array}{l}\text { Overweight and obesity } \\
\text { were related to higher risk } \\
\text { of work disability }\end{array}$ & $\begin{array}{l}\text { Risk of work disability was } \\
\text { higher for younger adults } \\
\text { ( }<65 \text { years) compared } \\
\text { with older adults ( }>65 \\
\text { years). Effect of obesity on } \\
\text { onset of cardiovascular } \\
\text { disease, long-term } \\
\text { medication use and } \\
\text { unhealthy life years was } \\
\text { also assessed }\end{array}$ \\
\hline Sturm $^{39}$ & 2004 & $50-69$ & $\begin{array}{l}\text { Longitudinal } \\
\text { study }\end{array}$ & $\begin{array}{l}\text { BMI with } \\
\text { WHO } \\
\text { cut-off } \\
\text { points }\end{array}$ & $\begin{array}{l}\text { Difficulty with ADL or } \\
\text { positive reports of } \\
\text { 'impairment or health } \\
\text { problem that limits the } \\
\text { kind/amount of paid } \\
\text { work' }\end{array}$ & $\begin{array}{l}\text { The probability of ADL } \\
\text { disability was } 50 \% \text { higher } \\
\text { for men with BMI } \\
\text { between 30-35, compared } \\
\text { with men with BMI } \\
\text { between 20-25. The } \\
\text { probability increased to } \\
300 \% \text { if BMI was }>35 \text {. } \\
\text { For women the effect is } \\
\text { larger with double the risk } \\
\text { for women with BMI } \\
\text { between } 30-35 \text { and four } \\
\text { times the risk for women } \\
\text { with BMI }>35\end{array}$ & Uses HRS study \\
\hline
\end{tabular}




\begin{tabular}{|c|c|c|c|c|c|c|c|}
\hline Reynolds ${ }^{38}$ & 2005 & $\geq 70$ & $\begin{array}{l}\text { Longitudinal } \\
\text { study }\end{array}$ & $\begin{array}{l}\text { BMI using } \\
\text { WHO } \\
\text { cut-off } \\
\text { point of } 30 \\
\text { to create } 2 \\
\text { categories } \\
\text { (obese } v s . \\
\text { non-obese) }\end{array}$ & $\begin{array}{l}\text { Difficulty in one or more } \\
\text { ADL }\end{array}$ & $\begin{array}{l}\text { Incidence of disability } \\
\text { between } 1993 \text { and } 1998 \\
\text { was higher for obese } \\
\text { adults compared with } \\
\text { non-obese adults (16.7 vs. } \\
\text { 12.7\%). Obese older } \\
\text { adults also had } \\
\text { significantly higher } \\
\text { probability of becoming } \\
\text { disabled compared with } \\
\text { non-obese adults }\end{array}$ & $\begin{array}{l}\text { Obesity had little effect on } \\
\text { life expectancy. Obesity } \\
\text { also affected likelihood of } \\
\text { recovering from disability }\end{array}$ \\
\hline Wilkins $^{42}$ & 2005 & $\geq 45$ & $\begin{array}{l}\text { Conducts } \\
\text { cross- } \\
\text { sectional } \\
\text { analysis } \\
\text { using data } \\
\text { from } \\
\text { CCHS in } \\
2003 \text { and } \\
\text { longitud- } \\
\text { inal } \\
\text { analysis } \\
\text { using data } \\
\text { from the } \\
\text { NPHS } \\
\text { waves 1-4 }\end{array}$ & $\begin{array}{l}\text { BMI with } \\
\text { WHO } \\
\text { cut-off } \\
\text { points }\end{array}$ & ADL/IADL & $\begin{array}{l}\text { Dependency in ADL/IADL } \\
\text { was almost the same for } \\
\text { older adults who were } \\
\text { underweight and those } \\
\text { with obesity class III }\end{array}$ & $\begin{array}{l}\text { Controlling for confounders } \\
\text { in stepwise at the end of } \\
\text { analysis. Obesity was } \\
\text { predictive of dependency } \\
\text { in ADL/IADL over time }\end{array}$ \\
\hline Al Snih ${ }^{36}$ & 2007 & $\geq 65$ & $\begin{array}{l}\text { Longitudinal } \\
\text { study }\end{array}$ & $\begin{array}{l}\text { BMI with } \\
\text { WHO } \\
\text { cut-off } \\
\text { points }\end{array}$ & $\begin{array}{l}\text { Difficulty with one or more } \\
\text { ADL }\end{array}$ & $\begin{array}{l}\text { A 'U'-shaped relationship } \\
\text { between BMI and } \\
\text { disability was observed. } \\
\text { Disability-free life } \\
\text { expectancy was highest } \\
\text { for older adults with BMI } \\
\text { between } 25-30\end{array}$ & $\begin{array}{l}\text { Used sample with } \\
\text { non-Hispanic Whites, } \\
\text { African-Americans and } \\
\text { Hispanics }\end{array}$ \\
\hline
\end{tabular}




\begin{tabular}{|c|c|c|c|c|c|c|c|}
\hline Author & Year & $\begin{array}{l}\text { Age of } \\
\text { participants }\end{array}$ & Type of study & $\begin{array}{l}\text { Obesity measure } \\
\text { used }\end{array}$ & Disability measure used & $\begin{array}{l}\text { Relationship between } \\
\text { obesity and disability }\end{array}$ & Notes \\
\hline Lang $^{25}$ & 2008 & $\geq 65$ & $\begin{array}{l}\text { Longitudinal } \\
\text { study }\end{array}$ & $\begin{array}{l}\text { BMI with WHO } \\
\text { cut-off points }\end{array}$ & $\begin{array}{l}\text { Self-reported and measured } \\
\text { physical function was } \\
\text { assessed. Self-reported } \\
\text { physical function was } \\
\text { assessed through difficulty } \\
\text { in one or more ADL. } \\
\text { Measured physical } \\
\text { function was assessed } \\
\text { through the SPPB; a score } \\
=7 \text { was considered } \\
\text { disability }\end{array}$ & $\begin{array}{l}\text { Rise in poor } \\
\text { self-reported and } \\
\text { measured physical } \\
\text { function with } \\
\text { increasing BMI. } \\
\text { Over time obese } \\
\text { were more likely to } \\
\text { develop disability } \\
\text { compared with } \\
\text { normal-weight } \\
\text { adults }\end{array}$ & Uses ELSA study \\
\hline Walter ${ }^{41}$ & 2009 & $\geq 55$ & $\begin{array}{l}\text { Longitudinal } \\
\text { study }\end{array}$ & $\begin{array}{l}\text { BMI with WHO } \\
\text { cut-off points } \\
\text { and WC divided } \\
\text { in three } \\
\text { categories for } \\
\text { men and women } \\
\text { separately }\end{array}$ & $\begin{array}{l}\text { ADL from the HAQ-DI } \\
\text { Index. HAQ-DI score }= \\
0.5 \text { was considered } \\
\text { disability }\end{array}$ & $\begin{array}{l}\text { Obesity doubles the } \\
\text { risk of disability } \\
\text { over time }\end{array}$ & $\begin{array}{l}\text { BMI also decreases the } \\
\text { probability of recovery } \\
\text { from disability over time }\end{array}$ \\
\hline Al Snih ${ }^{44}$ & 2010 & $\geq 65$ & $\begin{array}{l}\text { Cross- } \\
\text { sectional } \\
\text { study using } \\
\text { data from } \\
\text { the SABE } \\
\text { study that } \\
\text { included } 6 \\
\text { cities in } \\
\text { Latin } \\
\text { America }\end{array}$ & $\begin{array}{l}\text { WHO cut-off } \\
\text { points, separates } \\
\text { category I (BMI } \\
\text { between } 30 \text { and } \\
34.9) \text { from } \\
\text { category II and } \\
\text { extreme obesity } \\
(\mathrm{BMI} \geq 35)\end{array}$ & $\begin{array}{l}\text { Difficulty in one or more } \\
\text { ADL }\end{array}$ & $\begin{array}{l}\text { Obesity is an } \\
\text { independent factor } \\
\text { contributing to ADL } \\
\text { disability. Category } \\
\text { I and category II } \\
\text { obesity are } \\
\text { presented separately }\end{array}$ & $\begin{array}{l}\text { Variation by country } \\
\text { observed; however, } \\
\text { relationship present in all } \\
\text { countries }\end{array}$ \\
\hline Himes ${ }^{49}$ & 2000 & $\geq 70$ & $\begin{array}{l}\text { Cross- } \\
\text { sectional } \\
\text { study }\end{array}$ & $\begin{array}{l}\text { BMI with WHO } \\
\text { cut-off points }\end{array}$ & $\begin{array}{l}\text { Self-reported limitations in } \\
\text { one or more ADL or any } \\
\text { difficulty with one or } \\
\text { more items of the Nagi } \\
\text { disability scale }\end{array}$ & $\begin{array}{l}\text { As BMI increases, } \\
\text { ADL limitations } \\
\text { increase }\end{array}$ & $\begin{array}{l}\text { Effect of obesity on each } \\
\text { ADL was analysed and on } \\
\text { ADL and Nagi activities } \\
\text { separately. Effect of } \\
\text { obesity on five medical } \\
\text { conditions is also analysed }\end{array}$ \\
\hline
\end{tabular}




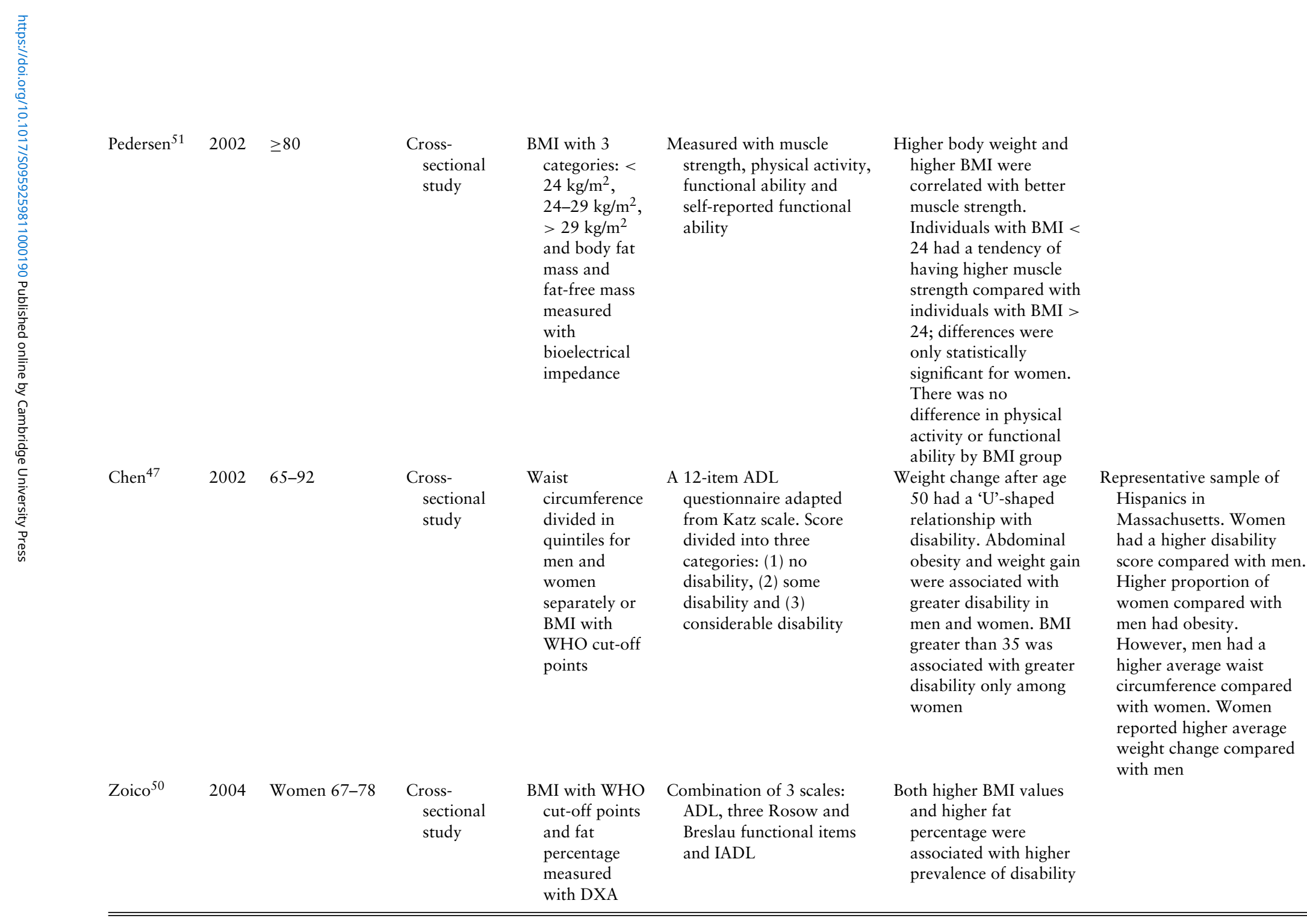


Table 2. (continued)

\begin{tabular}{|c|c|c|c|c|c|c|c|}
\hline Author & Year & $\begin{array}{l}\text { Age of } \\
\text { participants }\end{array}$ & Type of study & $\begin{array}{l}\text { Obesity } \\
\text { measure used }\end{array}$ & Disability measure used & $\begin{array}{l}\text { Relationship between } \\
\text { obesity and disability }\end{array}$ & Notes \\
\hline$\overline{\text { Woo }^{54}}$ & 2007 & $\geq 65$ & $\begin{array}{l}\text { Cross- } \\
\text { sectional } \\
\text { study }\end{array}$ & $\begin{array}{l}\text { BMI using } \\
\text { cut-off } \\
\text { point } \\
\text { previously } \\
\text { reported } \\
\text { for Asian } \\
\text { popula- } \\
\text { tions }\end{array}$ & $\begin{array}{l}\text { Physical activity level } \\
\text { determined through the } \\
\text { PASE scale or difficulty } \\
\text { performing one of the } \\
\text { following: walking } 2-3 \\
\text { blocks, climbing } 10 \text { steps, } \\
\text { meal preparation, doing } \\
\text { heavy house work and } \\
\text { shopping }\end{array}$ & $\begin{array}{l}\text { Older adults with category I } \\
\text { and category II obesity } \\
(\mathrm{BMI} \text { between } 25-29.9 \\
\mathrm{kg} / \mathrm{m}^{2} \text { and } \geq 30 \mathrm{~kg} / \mathrm{m}^{2} \text { ) } \\
\text { had greater number of } \\
\text { impairments performing } \\
\text { the different activities. A } \\
\text { 'U'-shape relationship } \\
\text { between BMI and physical } \\
\text { performance is reported }\end{array}$ & $\begin{array}{l}\text { Study using men and women } \\
\text { in Hong Kong. Additional } \\
\text { analyses show that fat } \\
\text { mass was associated with } \\
\text { physical function while } \\
\text { apendicular muscle mass } \\
\text { was not }\end{array}$ \\
\hline Alley ${ }^{45}$ & 2008 & $\geq 60$ & $\begin{array}{l}\text { Cross- } \\
\text { sectional } \\
\text { study using } \\
\text { data to } \\
\text { analyse } \\
\text { disability } \\
\text { trends in } \\
\text { the United } \\
\text { States }\end{array}$ & $\begin{array}{l}\text { BMI with } \\
\text { WHO } \\
\text { cut-off } \\
\text { points }\end{array}$ & $\begin{array}{l}\text { Two types of disability } \\
\text { indicators: }(1) \text { functional } \\
\text { limitations and (2) ADL }\end{array}$ & $\begin{array}{l}\text { At baseline, prevalence of } \\
\text { functional impairment } \\
\text { was lowest among the } \\
\text { normal weight adults } \\
(26.7 \%) \text { and increased for } \\
\text { overweight adults } \\
(27.4 \%) \text { and obese adults } \\
(36.8 \%) \text {; prevalence of } \\
\text { ADL impairment was } 5 \% \\
\text { for underweight, } 4.3 \% \text { for } \\
\text { overweight and } 6 \% \text { for } \\
\text { obese older adults. At } \\
\text { follow-up, the prevalence } \\
\text { of functional impairment } \\
\text { was } 26.6 \% \text { for normal } \\
\text { weight adults, } 25.8 \% \text { for } \\
\text { overweight and } 42.2 \% \text { for } \\
\text { obese older adults; } \\
\text { prevalence of ADL } \\
\text { impairment was } 3.5 \% \text { in } \\
\text { normal weight, } 3 \% \text { in } \\
\text { overweight and } 5.5 \% \text { in } \\
\text { obese }\end{array}$ & $\begin{array}{l}\text { 'J'-shape observed in the } \\
\text { relationship between } \\
\text { obesity and disability } \\
\text { reported in other studies, } \\
\text { for ADL disability at } \\
\text { baseline and follow-up } \\
\text { and for functional } \\
\text { impairment at follow-up. } \\
\text { Over time the prevalence } \\
\text { of functional impairment } \\
\text { increased for obese } \\
\text { individuals, but no change } \\
\text { was observed for ADL } \\
\text { impairment }\end{array}$ \\
\hline
\end{tabular}




\begin{tabular}{|c|c|c|c|c|c|c|c|}
\hline Chen $^{48}$ & 2008 & $\geq 60$ & $\begin{array}{l}\text { Cross- } \\
\quad \text { sectional } \\
\text { study }\end{array}$ & $\begin{array}{l}\text { Sex-specific } \\
\text { quartiles } \\
\text { and WHO } \\
\text { cut-off } \\
\text { points in } \\
\text { addition to } \\
\text { waist cir- } \\
\text { cumference }\end{array}$ & $\begin{array}{l}\text { A total of } 19 \text { questions to } \\
\text { assess the level of difficulty } \\
\text { in performing a physical } \\
\text { or mental task without } \\
\text { using special equipment } \\
\text { were used to measure } \\
\text { functional status. The } \\
\text { items were classified into } \\
\text { five domains: (1) ADL, (2) } \\
\text { IADL, (3) leisure and } \\
\text { social activities, (4) lower } \\
\text { extremity mobility, (5) } \\
\text { general physical activities. } \\
\text { Disability was defined as } \\
\text { with one or more activities } \\
\text { within a given domain }\end{array}$ & $\begin{array}{l}\text { BMI was positively } \\
\text { associated with all } \\
\text { measures of functional } \\
\text { disability in women and } \\
\text { with disability in all } \\
\text { domains but ADL and } \\
\text { IADL in men }\end{array}$ & $\begin{array}{l}\text { Waist circumference also } \\
\text { associated with disability. } \\
\text { Waist circumference is } \\
\text { suggested as a stronger } \\
\text { indicator of disability for } \\
\text { women compared with } \\
\text { men }\end{array}$ \\
\hline Rolland $^{52}$ & 2009 & $\begin{array}{l}\text { Women } 75 \text { or } \\
\text { older }\end{array}$ & $\begin{array}{l}\text { Cross- } \\
\text { sectional } \\
\text { study }\end{array}$ & $\begin{array}{l}\text { Percentage } \\
\text { body fat } \\
\text { above the } \\
\text { 60th } \\
\text { percentile } \\
\text { measured } \\
\text { with DXA }\end{array}$ & $\begin{array}{l}\text { Difficulty in } 3 \text { or more } \\
\text { mobility activities } \\
\text { (walking, climbing stairs, } \\
\text { going down stairs, rising } \\
\text { from chair or bed, picking } \\
\text { up object from floor, } \\
\text { lifting heavy object or } \\
\text { reaching for objects) }\end{array}$ & $\begin{array}{l}\text { Compared with the group } \\
\text { with normal body } \\
\text { composition, obese } \\
\text { women had } 44-79 \% \\
\text { higher odds of having } \\
\text { difficulty with functional } \\
\text { measures }\end{array}$ & $\begin{array}{l}\text { Association between obesity, } \\
\text { sarcopenia and their } \\
\text { combination with } \\
\text { disability was examined. } \\
\text { Obesity alone and } \\
\text { sarcopenia with obesity } \\
\text { both increase the risk of } \\
\text { disability }\end{array}$ \\
\hline Berraho $^{46}$ & 2010 & $\geq 65$ & $\begin{array}{l}\text { Cross- } \\
\text { sectional } \\
\text { study }\end{array}$ & $\begin{array}{l}\text { BMI with } \\
\text { WHO } \\
\text { cut-off } \\
\text { points }\end{array}$ & $\begin{array}{l}\text { Hierarchical index } \\
\text { aggregating three domains } \\
\text { of disability into a single } \\
\text { measure: mobility, ADL } \\
\text { and IADL. Individuals } \\
\text { were considered } \\
\text { dependent if they could } \\
\text { not perform at least one } \\
\text { activity of the domain } \\
\text { without help }\end{array}$ & $\begin{array}{l}\text { The highest proportion of } \\
\text { independent older adults } \\
\text { was among those with a } \\
\text { BMI range between } 25-30 \\
\mathrm{~kg} / \mathrm{m}^{2} \text {. The highest rates } \\
\text { of mobility disability were } \\
\text { observed in obese older } \\
\text { adults }\end{array}$ & $\begin{array}{l}\text { Differences observed in the } \\
\text { relationship between } \\
\text { obesity and disability } \\
\text { depending on type of } \\
\text { disability measured }\end{array}$ \\
\hline
\end{tabular}

women had 44-79\%

higher odds of having

difficulty with functiona

The highest proportion of independent older adults of mobility disability were observed in obese older 
Table 2. Continued.

\begin{tabular}{|c|c|c|c|c|c|c|c|}
\hline Author & Year & $\begin{array}{l}\text { Age of } \\
\text { participants }\end{array}$ & Type of study & $\begin{array}{l}\text { Obesity } \\
\text { measure used }\end{array}$ & Disability measure used & $\begin{array}{l}\text { Relationship between } \\
\text { obesity and disability }\end{array}$ & Notes \\
\hline Vincent $^{53}$ & 2010 & $\geq 60$ & $\begin{array}{l}\text { Literature } \\
\text { review } \\
\text { article with } \\
\text { cross- } \\
\text { sectional } \\
\text { and longit- } \\
\text { udinal } \\
\text { studies }\end{array}$ & $\begin{array}{l}\text { BMI, body } \\
\text { fat } \\
\text { percentage } \\
\text { or fat mass }\end{array}$ & $\begin{array}{l}\text { Mobility disability measure } \\
\text { with at least one of the } \\
\text { following: walk time, } \\
\text { walk distance, transfers, } \\
\text { chair rise to } \\
\text { timed-up-and-go test to } \\
\text { stair climb }\end{array}$ & $\begin{array}{l}\text { Cross-sectional studies show } \\
\text { that obesity is associated } \\
\text { with poor lower extremity } \\
\text { mobility in older men and } \\
\text { women. Most longitudinal } \\
\text { studies reported that } \\
\text { higher adiposity was } \\
\text { related to declining } \\
\text { mobility over time. } \\
\text { Walking, stair climbing, } \\
\text { and chair rise were } \\
\text { especially affected if BMI } \\
\text { was greater than } \\
35 \text { kg/m². Mobility } \\
\text { impairment in older obese } \\
\text { adults was more common } \\
\text { for women compared with } \\
\text { men }\end{array}$ & $\begin{array}{l}\text { A few interventional studies } \\
\text { reviewed provide evidence } \\
\text { that weight loss is related } \\
\text { to better mobility }\end{array}$ \\
\hline $\mathrm{Wee}^{43}$ & 2011 & $\geq 65$ & $\begin{array}{l}\text { Longitudinal } \\
\text { Study }\end{array}$ & $\begin{array}{l}\text { BMI with } \\
\text { WHO } \\
\text { cut-off } \\
\text { points }\end{array}$ & $\begin{array}{l}\text { Difficulty with one or more } \\
\text { ADL or difficulty with one } \\
\text { or more IADL }\end{array}$ & $\begin{array}{l}\text { Overweight and obesity } \\
\text { were associated with new } \\
\text { or progressive ADL and } \\
\text { IADL disability in a } \\
\text { dose-dependent manner, } \\
\text { particularly for white men } \\
\text { and women }\end{array}$ & $\begin{array}{l}\text { Obesity was not associated } \\
\text { with mortality, except for } \\
\text { those with at least } \\
\text { moderately severe obesity }\end{array}$ \\
\hline
\end{tabular}

CCHS, Canadian Community Health Survey; NPHS, National Population Health Survey in Canada; ADL, activities of daily living; IADL, instrumental activities of daily living; DXA, dual energy X-ray absorptiometry; ELSA, English Longitudinal Study on Ageing; HAQ-DI, Health Assessment Questionnaire Disability Index; HRS, Health Retirement Study; SABE, The Health, Well-Being and Ageing Survey; PASE, The Physical Activity Scale for the Elderly; WC, waist circumference; SPBB, Short Physical Performance Battery; WHO, World Health Organization; BMI, body mass index; WHO cut-off points, BMI $\geq 30 \mathrm{~kg} / \mathrm{m}^{2}$. 
Similar to the longitudinal studies, disability is defined in different ways. Of the 11 cross-sectional studies included, seven use ADL exclusively or in combination with other functionality measures to define disability. ${ }^{44-50}$ Three studies also use instrumental activities of daily living (IADL) to define disability. ${ }^{46,48,50}$ The remaining studies use either physical function or mobility disability to define disability. ${ }^{51-54}$ All studies conclude that obesity is related to increased disability regardless of how it is measured. Some of the studies analyse the relationship between obesity and muscle strength and suggest that, despite the deleterious effects of obesity on muscle function, additional pathways need to be analysed to understand the pathophysiology behind the onset of disability in older obese adults. ${ }^{50-54}$

Several studies report that the relationship between weight or BMI and disability has a ' $U$ ' or a 'J' shape, meaning that not only obesity but underweight older adults have increased risk of disability. ${ }^{36,45,48}$ Normal weight and some overweight older adults seem to have the lowest risk of disability of all weight or BMI groups. This has important implications for prevention and treatment schemes, since losing too much weight can be detrimental for older adults as well.

In summary, obesity is related to increased risk of disability among older adult populations. Obesity also seems to affect recovery from disability over time. Obesity not only affects functional status but it also affects mobility. Policy makers and healthcare providers need to keep this relationship in mind, and design obesity prevention and obesity management programmes that can improve functional status in older adults and protect them from becoming disabled, with resultant poor quality of life.

\section{Implications of obesity on chronic diseases}

Despite the widely know deleterious effects of obesity on overall health, obesity in older age has to be analysed with caution. Obesity significantly increases the risk of death among older adults. Nevertheless, the relationship between BMI and mortality is unique in the older adult population because very low BMI values are related to the highest mortality risk; this risk decreases as BMI increases to normal and overweight values and then mortality risk increases again, with a sharp increase in BMI values greater than
$35 \mathrm{~kg} / \mathrm{m}^{2} .{ }^{36,55,56}$ Additionally, weight loss has been reported as a risk factor for adverse events in some older adults including fractures, falls and mortality. ${ }^{57,58}$ Despite this, healthcare costs for older obese adults are higher than for older adults with normal weight. ${ }^{59,60}$ Similarly, disability rates and complications from obesity have been widely reported among the older adult population. ${ }^{61-63}$ We reviewed the literature and have summarized the implications of obesity on different diseases in the older adult population.

\section{Obesity and cardiovascular disease}

Obesity is an independent risk factor for development of heart failure, and acute events like myocardial infarctions and stroke in older adults. ${ }^{64,65}$ Obesity increases the risk of hypertension and affects overall response to anti-hypertensive medications. ${ }^{66-68} \mathrm{~A}$ 'U'-shaped relationship between BMI and hypertension has been reported. ${ }^{69}$ Two major causes have emerged as explanatory causes for cardiovascular disease resulting from obesity: anatomical and physiological alterations. Anatomical alterations are explained because obesity affects the architecture and physiology of the cardiovascular system. Obesity causes atrial and ventricular enlargement and plaque formation in the vessels. ${ }^{70-72}$ These changes not only affect cardiovascular function, but also increase the risk of developing potentially lethal conditions like atrial fibrillation and abdominal aortic aneurysms. ${ }^{73,74}$

Obesity triggers metabolic dysregulation and inflammation..$^{50,75,76}$ Decreased levels of natriuretic peptide, a peptide that protects against acute events like myocardial infarctions, have been reported. ${ }^{68,77}$ Other physiological alterations include increased levels of inflammatory markers (interleukin-6, C-reactive protein and tumour necrosis factor) that affect the body's response to physiological changes and put an additional burden on the cardiovascular system. ${ }^{76}$ Increased adiposity enhances insulin resistance and therefore the risk for adverse cardiovascular events overall. $^{50,78}$

\section{Obesity, diabetes and the metabolic syndrome}

Obesity, diabetes and the metabolic syndrome are closely related. Obesity and diabetes are distinct 
clinical conditions that occur independently despite sharing some pathophysiological pathways. The metabolic syndrome is also independent from obesity and diabetes. It is a collection of risk factors that cause damage to the cardiovascular system, increasing the risk of heart attack, stroke and other cardiovascular diseases. Increased body fat and increased blood sugar are two of the five components of the metabolic syndrome. ${ }^{79,80}$

Unlike the relationship between obesity and mortality in older adults, the relationship between obesity, diabetes and the metabolic syndrome is very similar in older adults compared with younger adults. A large body of evidence has shown that obesity increases the risk of developing diabetes and the metabolic syndrome. ${ }^{80,81}$ There is also evidence that obesity, diabetes and the metabolic syndrome are independent risk factors for cardiovascular disease. ${ }^{80}$ Increased oxidative stress in fatty tissue of obese individuals has been proposed as a pathogenic mechanism leading to the metabolic syndrome. ${ }^{82}$ Additionally, severity of obesity (determined by National Heart Lung and Blood Institute Task Force categories: class 1, class 2 and class 3 ) is associated with an increasing trend in risk of development of diabetes and the metabolic syndrome. ${ }^{83}$ It has been reported that this relationship between obesity, diabetes and the metabolic syndrome is especially important among minority populations in developed countries given the higher rates of obesity compared with other population groups and the higher rates of complications and mortality. ${ }^{79}$

\section{Obesity and cancer}

More than $60 \%$ of cancers occur over the age of $65 .{ }^{84}$ In the last decade, findings in cancer epidemiology have highlighted the importance of the relationship between obesity and cancer. ${ }^{85}$ Increased body mass and adiposity have been established as risk factors for the development of cancers that affect a large portion of the older adult population, such as colon cancer, breast cancer and prostate cancer. ${ }^{85}$ Three hormonal systems have been proposed as causal pathways: insulin and insulin-like growth factor axis, sex steroids and adipokines. ${ }^{85,86}$ These hormonal systems are altered in obesity; however, their role in the development of cancer is probably different for each cancer site. Additionally, the link between obesity and cancer seems to be different for men and women. ${ }^{85-87}$

To date there have been no clinical trials exploring the effect of losing weight, or even maintaining weight, on cancer incidence..$^{85,86}$ However, there is evidence from observational studies that weight maintenance and controlled weight loss may decrease the risk of developing some types of cancers. ${ }^{88,89}$ Despite the limited information, it has been shown that obesity increases the risk of delayed cancer diagnosis, complications during cancer treatment and poor outcomes after treatment. ${ }^{90,91}$

\section{Obesity and arthritis}

A common limitation when addressing arthritis in older adults is the lack of differentiation between the types of arthritis described. The most common types of arthritis affecting older adults are osteoarthritis, rheumatoid arthritis and gout. The pathophysiology, treatment and course of each type of arthritis are very different. However, the negative effect of arthritis on older adults is mostly due to its effect on overall physical and mental health and disability, rather than a direct increase in mortality risk. ${ }^{92}$

The relationship between obesity and arthritis has not been completely explained. Despite the differences in the most common types of arthritis in older adults, both obesity and arthritis are pro-inflammatory conditions that increase the concentration of cytokines and adipokines as previously reported. ${ }^{93}$ Additionally, arthritis impairs physical activity, necessary for weight loss and a cornerstone for self-management of arthritis because it diminishes pain and improves physical function. ${ }^{92,94}$ Both increased levels of inflammatory markers and decreased physical activity in relation to obesity impede adequate management of arthritis and increase the longterm effects of the disease. ${ }^{95}$ In addition, obesity accelerates the deterioration of joint function in older adults with arthritis and negatively affects some outcomes from surgical interventions. ${ }^{92,95}$

\section{Obesity and some geriatric syndromes}

Obesity has been linked to some geriatric syndromes. The pro-inflammatory state caused by obesity has been linked to age-related muscle loss or sarcopenia. ${ }^{4,50}$ Sarcopenia has been 
shown to increase disability and overall mortality and may explain some of the complications reported in obese older adults. ${ }^{4}$ Sarcopenia and obesity are independent conditions with separate pathophysiological pathways. However, older adults with co-morbid sarcopenia and obesity have become the centre of several studies. Cooccurrence of sarcopenia and obesity places older adults in a unique state of disease that increases the risk of adverse events and requires special interventions. ${ }^{4,50,52,54}$ Additionally, the pro-inflammatory state has also been related to vascular dysfunction in the brain that increases the production of beta-amyloid, a key component of senile plaques that accumulate in the brain in Alzheimer's disease. ${ }^{96-98}$

In summary, the pro-inflammatory state caused by obesity, in addition to the limitations in physical function, are common links to the added burden of disease when obesity is present concomitantly with many chronic conditions in older adults. Additionally, obesity is a marker of poor outcomes for most interventions for chronic conditions and interferes with management of most chronic diseases in older adults.

\section{Conclusion}

Obesity among older adults has increased noticeably in the last two decades in all continents. However, large variations between countries, race/ethnic groups and genders are observed. Obesity is related to increased risk of disability among older adult populations regardless of the measures used. Obesity affects functional status and mobility. Inflammation caused by obesity is linked to the added burden of disease when obesity is present concomitantly with many chronic conditions in older adults. Additionally, it is a marker of poor outcomes for most interventions for chronic conditions and interferes with management of most chronic diseases in older adults.

Policy makers and healthcare providers need to keep obesity-related health outcomes in mind and design obesity prevention and management programmes that can improve functional status in older adults and protect them from becoming disabled with resultant poor quality of life.

\section{Conflicts of interest}

The authors have nothing to disclose.

\section{Acknowledgements}

This study was supported by grants R03AG029959, R01-AG017638 and R01-AG010939 from the National Institute on Aging, USA. Dr Al Snih is supported by a research career development award (K12HD052023: Building Interdisciplinary Research Careers in Women's Health ProgramBIRCWH) from the Eunice Kennedy Shriver National Institute of Child Health \& Human Development; the National Institute of Allergy and Infectious Diseases; and the Office of the Director, National Institutes of Health.

\section{References}

1 WHO. Obesity and Overweight. 2011. Report No. 311.

2 Neovius K, Rasmussen F, Sundstrom J, Neovius $\mathrm{M}$. Forecast of future premature mortality as a result of trends in obesity and smoking: nationwide cohort simulation study. Eur J Epidemiol 2010; 25: 703-9.

3 Stewart ST, Cutler DM, Rosen AB. Forecasting the effects of obesity and smoking on US life expectancy. N Engl J Med 2009; 361: 225260.

4 Zamboni M, Mazzali G, Zoico E, Harris TB, Meigs JB, Di Francesco V, Fantin F, Bissoli L, Bosello O. Health consequences of obesity in the elderly: a review of four unresolved questions. Int J Obes (Lond) 2005; 29: 1011-29.

5 Bleich SN, Wang YC, Wang Y, Gortmaker SL. Increasing consumption of sugar-sweetened beverages among US adults: 1988-1994 to 1999-2004. Am J Clin Nutr 2009; 89: 372-81.

6 Cohen JD, Cziraky MJ, Cai Q, Wallace A, Wasser T, Crouse JR, Jacobson TA. 30-year trends in serum lipids among United States adults: results from the National Health and Nutrition Examination Surveys II, III, and 1999-2006. Am J Cardiol 2010; 106: 969-75.

7 Crimmins EM, Alley D, Reynolds SL, Johnston M, Karlamangla A, Seeman T. Changes in biological markers of health: older Americans in the 1990s. J Gerontol A Biol Sci Med Sci 2005; 60: 1409-13.

8 Flegal KM, Carroll MD, Ogden CL, Curtin LR. Prevalence and trends in obesity among US adults, 1999-2008. JAMA 2010; 303: 235-41.

9 Ford ES, Li C, Zhao G, Pearson WS, Capewell S. Trends in the prevalence of low risk factor burden for cardiovascular disease among United States adults. Circulation 2009; 120: 1181-88.

10 Ford ES, Li C, Zhao G, Tsai J. Trends in obesity and abdominal obesity among adults in the United 
States from 1999-2008. Int J Obes (Lond) 2011; 35: 736-43.

11 Stenholm S, Simonsick EM, Ferrucci L. Secular trends in body weight in older men born between 1877 and 1941: the Baltimore Longitudinal Study of Ageing. J Gerontol A Biol Sci Med Sci 2010; 65: 105-10.

12 Kaplan MS, Huguet N, Newsom JT, McFarland $\mathrm{BH}$, Lindsay J. Prevalence and correlates of overweight and obesity among older adults: findings from the Canadian National Population Health Survey. J Gerontol A Biol Sci Med Sci 2003; 58: 1018-30.

13 Torrance GM, Hooper MD, Reeder BA. Trends in overweight and obesity among adults in Canada (1970-1992): evidence from national surveys using measured height and weight. Int J Obes Relat Metab Disord 2002; 26: 797-804.

14 Macdonald SM, Reeder BA, Chen Y, Despres JP. Obesity in Canada: a descriptive analysis. Canadian Heart Health Surveys Research Group. CMAJ 1997; 157 suppl 1: S3-9.

15 Bruce SG, Riediger ND, Zacharias JM, Young TK. Obesity and obesity-related comorbidities in a Canadian First Nation population. Chronic Dis Can 2010; 31: 27-32.

16 Lix LM, Bruce S, Sarkar J, Young TK. Risk factors and chronic conditions among Aboriginal and non-Aboriginal populations. Health Rep 2009; 20: 21-29.

17 Al Snih S, Ray L, Markides KS. Prevalence of self-reported arthritis among elders from Latin America and the Caribbean and among Mexican Americans from the southwestern United States. J Ageing Health 2006; 18: 207-23.

18 Monteiro CA, Conde WL, Popkin BM. Income-specific trends in obesity in Brazil: 1975-2003. Am J Public Health 2007; 97: 1808-12.

19 Ruiz-Arregui L, Castillo-Martinez L, Orea-Tejeda A, Mejia-Arango S, Miguel-Jaimes A. Prevalence of self-reported overweight-obesity and its association with socioeconomic and health factors among older Mexican adults. Salud Publica Mex 2007; 49 suppl 4: S482-87.

20 Kotseva K, Wood D, De BG, De BD, Pyorala K, Keil U. Cardiovascular prevention guidelines in daily practice: a comparison of EUROASPIRE I, II, and III surveys in eight European countries. Lancet 2009; 373: 929-40.

21 Andreyeva T, Michaud PC, van Soest A. Obesity and health in Europeans aged 50 years and older. Public Health 2007; 121: 497-509.

22 Charles MA, Eschwege E, Basdevant A. Monitoring the obesity epidemic in France: the Obepi surveys 1997-2006. Obesity (Silver Spring) 2008; 16: 2182-86.
23 Dugravot A, Sabia S, Stringhini S, Kivimaki M, Westerlund H, Vahtera J, Guéguen A, Zins M, Goldberg M, Nabi H, Singh-Manoux A. Do socioeconomic factors shape weight and obesity trajectories over the transition from midlife to old age? Results from the French GAZEL cohort study. Am J Clin Nutr 2010; 92: 16-23.

24 Hubbard RE, Lang IA, Llewellyn DJ, Rockwood K. Frailty, body mass index, and abdominal obesity in older people. J Gerontol A Biol Sci Med Sci 2010; 65: 377-81.

25 Lang IA, Llewellyn DJ, Alexander K, Melzer D. Obesity, physical function, and mortality in older adults. I Am Geriatr Soc 2008; 56: 147478.

26 Morabia A, Costanza MC. The obesity epidemic as harbinger of a metabolic disorder epidemic: trends in overweight, hypercholesterolemia, and diabetes treatment in Geneva, Switzerland, 1993-2003. Am J Public Health 2005; 95: 632-35.

27 Gomez-Cabello A, Pedrero-Chamizo R, Olivares PR, Luzardo L, Juez-Bengoechea A, Mata E et al. Prevalence of overweight and obesity in non-institutionalized people aged 65 or over from Spain: the elderly EXERNET multi-centre study. Obes Rev 2011; 12: 583-92.

28 Michaud PC, van Soest A, Andreyeva T. Cross-country variation in obesity patterns among older Americans and Europeans. Research Paper. SEDAP; 2007. Report No. 185.

29 Young TK, Bjerregaard P, Dewailly E, Risica PM, Jorgensen ME, Ebbesson SE. Prevalence of obesity and its metabolic correlates among the circumpolar Inuit in 3 countries. Am J Public Health 2007; 97: 691-95.

30 WHO. The Asia-Pacific perspective: Redefining obesity and its treatment. Health Communications Australia; 2001.

31 AIHW; Bennet SA, Magnus P, Gibson D. Obesity trends in older Australians. Canberra: Australian Institute of Health and Welfare; 2004. Report No. 12.

32 Fried LP, Ferrucci L, Darer J, Williamson JD, Anderson G. Untangling the concepts of disability, frailty, and comorbidity: implications for improved targeting and care. J Gerontol A Biol Sci Med Sci 2004; 59: 255-63.

33 Guralnik JM, Simonsick EM, Ferrucci L, Glynn RJ, Berkman LF, Blazer DG, Scherr PA, Wallace RB. A short physical performance battery assessing lower extremity function: association with self-reported disability and prediction of mortality and nursing home admission. J Gerontol 1994; 49: M85-94.

34 Terry DF, Sebastiani P, Andersen SL, Perls TT. Disentangling the roles of disability and morbidity 
in survival to exceptional old age. Arch Intern Med 2008; 168: 277-83.

35 Verbrugge LM, Reoma JM, Gruber-Baldini AL. Short-term dynamics of disability and well-being. J Health Soc Behav 1994; 35: 97-117.

36 Al Snih S, Ottenbacher KJ, Markides KS, Kuo YF, Eschbach K, Goodwin JS. The effect of obesity on disability vs mortality in older Americans. Arch Intern Med 2007; 167: 774-80.

37 Ferraro KF, Su YP, Gretebeck RJ, Black DR, Badylak SF. Body mass index and disability in adulthood: a 20-year panel study. Am J Public Health 2002; 92: 834-40.

38 Reynolds SL, Saito Y, Crimmins EM. The impact of obesity on active life expectancy in older American men and women. Gerontologist 2005; 45: 438-44.

39 Sturm R, Ringel JS, Andreyeva T. Increasing obesity rates and disability trends. Health Aff (Millwood) 2004; 23: 199-205.

40 Visscher TL, Rissanen A, Seidell JC, Heliovaara M, Knekt P, Reunanen A, Aromaa A. Obesity and unhealthy life-years in adult Finns: an empirical approach. Arch Intern Med 2004; 164: 141320.

41 Walter S, Kunst A, Mackenbach J, Hofman A, Tiemeier H. Mortality and disability: the effect of overweight and obesity. Int J Obes (Lond) 2009; 33: 1410-18.

42 Wilkins K, de Groh M. Body mass and dependency. Health Reports 2005; 17: 27-39.

43 Wee CC, Huskey KW, Ngo LH, Fowler-Brown A, Leveille SG, Mittlemen MA, McCarthy EP. Obesity, race, and risk for death or functional decline among medicare beneficiaries: a cohort study. Ann Intern Med 2011; 154: 645-55.

44 Al Snih S, Graham JE, Kuo YF, Goodwin JS, Markides KS, Ottenbacher KJ. Obesity and disability: relation among older adults living in Latin America and the Caribbean. Am J Epidemiol 2010; 171: 1282-88.

45 Alley DE, Chang VW. The changing relationship of obesity and disability, 1988-2004. JAMA 2007; 298: 2020-27.

46 Berraho M, Nejjari C, Raherison C, El AY, Tachfouti N, Serhier Z, Dartigues JF, Barberger-Gateau P. Body mass index, disability, and 13-year mortality in older French adults. J Ageing Health 2010; 22: 68-83.

47 Chen H, Bermudez OI, Tucker KL. Waist circumference and weight change are associated with disability among elderly Hispanics. J Gerontol A Biol Sci Med Sci 2002; 57: M19-M25.

48 Chen H, Guo X. Obesity and functional disability in elderly Americans. J Am Geriatr Soc 2008; 56: 689-94.
49 Himes CL. Obesity, disease, and functional limitation in later life. Demography 2000; 37: 73-82.

50 Zoico E, Di Francesco V, Guralnik JM, Mazzali G, Bortolani A, Guariento S, Sergi G, Bosello O, Zamboni M. Physical disability and muscular strength in relation to obesity and different body composition indexes in a sample of healthy elderly women. Int J Obes Relat Metab Disord 2004; 28: 234-41.

51 Pedersen AN, Ovesen L, Schroll M, Avlund K, Era P. Body composition of 80 -years old men and women and its relation to muscle strength, physical activity and functional ability. $J$ Nutr Health Ageing 2002; 6: 413-20.

52 Rolland Y, Lauwers-Cances V, Cristini C, Abellan Van KG, Janssen I, Morley JE, Vellas B.

Difficulties with physical function associated with obesity, sarcopenia, and sarcopenic-obesity in community-dwelling elderly women: the EPIDOS (EPIDemiologie de l'OSteoporose) Study. Am J Clin Nutr 2009; 89: 1895-900.

53 Vincent HK, Vincent KR, Lamb KM. Obesity and mobility disability in the older adult. Obes Rev 2010; 11: 568-79.

54 Woo J, Leung J, Kwok T. BMI, body composition, and physical functioning in older adults. Obesity (Silver Spring) 2007; 15: 1886-94.

55 Auyeung TW, Lee JS, Leung J, Kwok T, Leung PC, Woo J. Survival in older men may benefit from being slightly overweight and centrally obese - a 5-year follow-up study in 4,000 older adults using DXA. J Gerontol A Biol Sci Med Sci 2010; 65: 99-104.

56 Kapoor JR, Heidenreich PA. Obesity and survival in patients with heart failure and preserved systolic function: a U-shaped relationship. Am Heart J 2010; 159: 75-80.

57 Amador LF, Al SS, Markides KS, Goodwin JS. Weight change and mortality among older Mexican Americans. Ageing Clin Exp Res 2006; 18: 196-204.

58 Locher JL, Roth DL, Ritchie CS, Cox K, Sawyer P, Bodner EV, Allman RM. Body mass index, weight loss, and mortality in community-dwelling older adults. J Gerontol A Biol Sci Med Sci 2007; 62: 1389-92.

59 Daviglus ML, Liu K, Yan LL, Pirzada A, Manheim L, Manning W, Garside DB, Wang R, Dyer AR, Greenland P, Stamler J. Relation of body mass index in young adulthood and middle age to Medicare expenditures in older age. JAMA 2004; 292: 2743-49.

60 Raebel MA, Malone DC, Conner DA, Xu S, Porter JA, Lanty FA. Health services use and health care costs of obese and non-obese individuals. Arch Intern Med 2004; 164: 2135-40. 
61 Nafiu OO, Kheterpal S, Moulding R, Picton P, Tremper KK, Campbell DA Jr, Eliason JL, Stanley JC. The association of body mass index to postoperative outcomes in elderly vascular surgery patients: a reverse J-curve phenomenon. Anesth Analg 2011; 112: 23-29.

62 Schafer MH, Ferraro KF. Long-term obesity and avoidable hospitalization among younger, middle-aged, and older adults. Arch Intern Med 2007; 167: 2220-25.

63 Zacharias A, Schwann TA, Riordan CJ, Durham SJ, Shah AS, Habib RH. Obesity and risk of new-onset atrial fibrillation after cardiac surgery. Circulation 2005; 112: 3247-55.

64 Caterson ID, Hubbard V, Bray GA, Grunstein R, Hansen BC, Hong Y, Labarthe D, Seidell JC, Smith SC Jr; American Heart Association. Prevention Conference VII: Obesity, a worldwide epidemic related to heart disease and stroke: Group III: worldwide comorbidities of obesity. Circulation 2004; 110: e476-83.

65 Kurth T, Gaziano JM, Berger K, Kase CS, Rexrode KM, Cook NR, Buring JE, Manson JE. Body mass index and the risk of stroke in men. Arch Intern Med 2002; 162: 2557-62.

66 Hayashi T, Boyko EJ, Leonetti DL, McNeely MJ, Newell-Morris L, Kahn SE, Fujimoto WY. Visceral adiposity is an independent predictor of incident hypertension in Japanese Americans. Ann Intern Med 2004; 140: 992-1000.

67 Kaplan NM. Resistant hypertension: what to do after trying 'the usual'. Geriatrics 1995; 50: 24-30.

68 Wang TJ, Larson MG, Levy D, Benjamin EJ, Leip EP, Wilson PW, Vasan RS. Impact of obesity on plasma natriuretic peptide levels. Circulation 2004; 109: 594-600.

69 Uretsky S, Messerli FH, Bangalore S, Champion A, Cooper-Dehoff RM, Zhou Q, Pepine CJ. Obesity paradox in patients with hypertension and coronary artery disease. Am J Med 2007; 120: 863-70.

70 Al Suwaidi J, Higano ST, Hamasaki S, Holmes DR, Lerman A. Association between obesity and coronary atherosclerosis and vascular remodeling. Am J Cardiol 2001; 88: 1300-3.

71 Al Suwaidi J, Higano ST, Holmes DR Jr, Lennon $\mathrm{R}$, Lerman A. Obesity is independently associated with coronary endothelial dysfunction in patients with normal or mildly diseased coronary arteries. J Am Coll Cardiol 2001; 37: 1523-28.

72 Russo C, Jin Z, Homma S, Rundek T, Elkind MS, Sacco RL, Di Tullio MR. Effect of obesity and overweight on left ventricular diastolic function: a community-based study in an elderly cohort. J Am Coll Cardiol 2011; 57: 1368-74.

73 Dublin S, French B, Glazer NL, Wiggins KL, Lumley T, Psaty BM, Smith NL, Heckbert SR.
Risk of new-onset atrial fibrillation in relation to body mass index. Arch Intern Med 2006; 166: 2322-28.

74 Golledge J, Clancy P, Jamrozik K, Norman PE. Obesity, adipokines, and abdominal aortic aneurysm: Health in Men study. Circulation 2007; 116: 2275-79.

75 Bahrami H, Bluemke DA, Kronmal R, Bertoni AG, Lloyd-Jones DM, Shahar E, Szklo M, Lima JA. Novel metabolic risk factors for incident heart failure and their relationship with obesity: the MESA (Multi-Ethnic Study of Atherosclerosis) study. J Am Coll Cardiol 2008; 51: 1775-83.

76 Fontana L, Eagon JC, Trujillo ME, Scherer PE, Klein S. Visceral fat adipokine secretion is associated with systemic inflammation in obese humans. Diabetes 2007; 56: 1010-13.

77 Lorgis L, Cottin Y, Danchin N, Mock L, Sicard P, Buffet P, L'huillier I, Richard C, Beer JC, Touzery C, Gambert P, Zeller M; RICO survey working group. Impact of obesity on the prognostic value of the N-terminal pro-B-type natriuretic peptide (NT-proBNP) in patients with acute myocardial infarction. Heart 2011; 97: 551-56.

78 Karter AJ, Mayer-Davis EJ, Selby JV, D’Agostino RB Jr, Haffner SM, Sholinsky P, Bergman R, Saad MF, Hamman RF. Insulin sensitivity and abdominal obesity in African-American, Hispanic, and non-Hispanic white men and women. The Insulin Resistance and Atherosclerosis Study. Diabetes 1996; 45: 1547-55.

79 Smith SC Jr. Clark LT, Cooper RS, Daniels SR, Kumanyika SK, Ofili E, Quinones MA, Sanchez EJ, Saunders E, Tiukinhoy SD; American Heart Association Obesity, Metabolic Syndrome, and Hypertension Writing Group. Discovering the full spectrum of cardiovascular disease: Minority Health Summit 2003: report of the Obesity, Metabolic Syndrome, and Hypertension Writing Group. Circulation 2005; 111: e13439.

80 Vega GL. Results of Expert Meetings: Obesity and Cardiovascular Disease. Obesity, the metabolic syndrome, and cardiovascular disease. Am Heart J 2001; 142: 1108-16.

81 Goodpaster BH, Krishnaswami S, Harris TB, Katsiaras A, Kritchevsky SB, Simonsick EM, Nevitt M, Holvoet P, Newman AB. Obesity, regional body fat distribution, and the metabolic syndrome in older men and women. Arch Intern Med 2005; 165: 777-83.

82 Furukawa S, Fujita T, Shimabukuro M, Iwaki M, Yamada Y, Nakajima Y, Nakayama O, Makishima M, Matsuda M, Shimomura I. Increased oxidative stress in obesity and its impact on metabolic syndrome. J Clin Invest 2004; 114: 1752-61. 
83 Ruland S, Hung E, Richardson D, Misra S, Gorelick PB. Impact of obesity and the metabolic syndrome on risk factors in African American stroke survivors: a report from the AAASPS. Arch Neurol 2005; 62: 386-90.

84 ASCO. Cancer in Older Adults. 2010. American Society of Clinical Oncology.

85 Renehan AG. Epidemiology of overweight/obesity and cancer risk. In McTiernan A (ed), Physical Activity, Dietary Calorie Restriction and Cancer, pp. 5-23. New York: Springer; 2010.

86 Renehan AG, Roberts DL, Dive C. Obesity and cancer: pathophysiological and biological mechanisms. Arch Physiol Biochem 2008; 114: 71-83.

87 Kelly T, Yang W, Chen CS, Reynolds K, He J. Global burden of obesity in 2005 and projections to 2030. Int J Obes (Lond) 2008; 32: 1431-37.

88 Frezza EE, Wachtel MS, Chiriva-Internati M. Influence of obesity on the risk of developing colon cancer. Gut 2006; 55: 285-91.

89 NCI. Obesity and cancer: questions and answers. 2004.

90 Renehan AG, Soerjomataram I, Leitzmann MF. Interpreting the epidemiological evidence linking obesity and cancer: A framework for population-attributable risk estimations in Europe. Eur J Cancer 2010; 46: 2581-92.

91 Roberts DL, Dive C, Renehan AG. Biological mechanisms linking obesity and cancer risk: new perspectives. Ann Rev Med 2010; 61: 301-16.

92 Reynolds SL, McIlvane JM. The impact of obesity and arthritis on active life expectancy in older Americans. Obesity (Silver Spring) 2009; 17: 363-69.

93 Gomez R, Lago F, Gomez-Reino J, Dieguez C, Gualillo O. Adipokines in the skeleton: influence on cartilage function and joint degenerative diseases. J Mol Endocrinol 2009; 43: 1118.

94 Stavropoulos-Kalinoglou A, Metsios GS, Koutedakis Y, Kitas GD. Obesity in rheumatoid arthritis. Rheumatology (Oxford) 2011; 50: 450-62.

95 Toivanen AT, Heliovaara M, Impivaara O, Arokoski JP, Knekt P, Lauren H, Kröger H. Obesity, physically demanding work and traumatic knee injury are major risk factors for knee osteoarthritis - a population-based study with a follow-up of 22 years. Rheumatology (Oxford) 2010; 49: 308-14.

96 Craft S. The role of metabolic disorders in Alzheimer disease and vascular dementia: two roads converged. Arch Neurol 2009; 66: $300-5$.

97 Kingwell K. Dementia: Overweight or obesity during midlife is associated with late-life dementia. Nat Rev Neurol 2011; 7: 299.

$98 \mathrm{Xu}$ WL, Atti AR, Gatz M, Pedersen NL, Johansson B, Fratiglioni L. Midlife overweight and obesity increase late-life dementia risk: a population-based twin study. Neurology 2011; 76: 1568-74.

99 Banks J, Marmot M, Oldfield Z, Smith JP. Disease and disadvantage in the United States and in England. JAMA 2006; 295: 2037-45.

100 Avendano M, Glymour MM, Banks J, Mackenbach JP. Health disadvantage in US adults aged 50 to 74 years: a comparison of the health of rich and poor Americans with that of Europeans. Am J Public Health 2009; 99: 540-48. 